Gisle Roksund (f. 1951) er spesialist i allmenn- og samfunnsmedisin. Fastlege ved Klosterhagen legesenter i Skien.

Ingen oppgitte interessekonflikter.

Sigbjørn Taksdal (f. 1932) er spesialist i urologi og pensjonert overlege. Ingen oppgitte interessekonflikter.

John Brodersen (f.1963) er lektor, PhD. Spesiallæge i almen medicin, Københavns Universitet.

Ingen oppgitte interessekonflikter.

Litteratur

1. Johansen TEB. Den vanskelige prostatakreften. Tidsskr Nor Legeforen 2015; 135: 508 .

2. Raabe NK, Normann M, Lilleby W. Lavdoserate brakyterapi ved lavgradig prostatakreft. Tidsskr Nor Legeforen 2015; 135: 548-52.

\section{Redaktøren svarer:}

Vi takker for kommentar fra Roksund og medarbeidere. Forfatterne spør hvordan Tidsskriftet kan være bekjent av en oversiktsartikkel som ikke «identifiserer artikler med et design som gir høyt evidensnivå, anvender omforente kriterier for inklusjon og oppfølging og bruker kliniske effektmål».

Oversiktsartikkelen har gjennomgått vanlig redaksjonell vurdering i Tidsskriftet, samt faglig vurdering ved to eksterne fagvurderere. Forfatterne har beskrevet søkeprosessen og eksklusjonskriteriene. De gjør rede for at det mangler gode prospektive randomiserte multisenterstudier med totaloverlevelse som endepunkt. At det ikke finnes gode studier, betyr ikke at eksisterende kunnskap ikke bør oppsummeres.

En annen sak er om det kan trekkes sikre konklusjoner når studiene ikke har tilstrekkelig kvalitet. Forfatternes anbefalinger og konklusjoner er basert på deres egen vurdering av resultatene. I vår redaksjonelle prosess undersøker vi om konklusjonen er rimelig å trekke på bakgrunn av resultatene - men det betyr ikke at vi går god for at det er den eneste rimelige konklusjonen som kan trekkes. I denne artikkelen var det åpenbart at forfatternes konklusjon er kontroversiell. Derfor ønsket vi en lederartikkel som kunne sette artikkelen inn i et større perspektiv.

Når det gjelder interessekonflikter følger Tidsskriftet internasjonal praksis i medisinsk vitenskapelige tidsskrifter. I tråd med dette må alle forfattere fylle ut interessekonfliktskjemaet fra International Committee of Medical Journal Editors (ICMJE) (1). Tidsskriftet driver normalt ikke egne undersøkelser for å avdekke mulige interessekonflikter, vi baserer oss på forfatternes egenerklæring. Der hvor vi er i tvil spør vi forfatterne under prosessen, så også når det gjaldt denne artikkelen. Når Roksund et al nå fremmer mistanke om at forfatterne har økonomiske interesser av konklusjonene som fremkommer i artikkelen, har vi fulgt Committee of Publication Ethics (COPE) sin anbefaling i slike saker (2): Mistanken er videreformidlet til forfatterne, og vi har bedt dem svare på denne. Forfatterne mener at de ikke har interessekonflikter knyttet til artikkelen, og har avgitt følgende svar: «Nils Kristian Raabe ble pensjonert fra en overlegestilling på Radiumhospitalet for 2 år siden. Han driver en privatpraksis tre ettermiddager i måneden hos en fastlege på CC-Vest legesenter der han hovedsakelig driver småkirurgi. Lavdoserate brakyterapi er en høyteknologisk behandling som kun bør gis ved sykehus med utstyr og spesialkompetanse for strålebehandling. Marius Normann er ansatt som fagansvarlig onkolog ved Aleris Kreftsenter i Oslo. I tråd med nasjonale og internasjonale retningslinjer anbefaler Aleris kun behandling til pasienter med prostatakreft i høy eller intermediær risikogruppe. Aleris tilbyr ingen egen behandling av prostatacancer og har ingen kommersiell interesse av hvilken behandling pasienten mottar. Aleris har ingen kommersiell interesse av lavdoserate brakyterapi, og hverken tilbyr eller har planer om å tilby behandlingen.»

Are Brean

are.brean@legeforeningen.no

Sigurd Høye
Are Brean (f. 1965) er konstituert sjefredaktør i Tidsskrift for Den norske legeforening

Ingen oppgitte interessekonflikter.

Sigurd Høye (f. 1972) er medisinsk redaktør i Tidsskrift for Den norske legeforening.

Ingen oppgitte interessekonflikter.

\section{Litteratur}

1. http://tidsskriftet.no/Innhold/Forfatterveiledningen/Etikk-og-jus/ Interessekonflikter (3.5.2015)

2. What to do if a reader suspects undisclosed conflict of interest (Col) in a published article. http://publicationethics.org/files/u7140/COl\%20published pdf (3.5.2015).

\section{Re: Hva er god behandling ved akutt hjerneslag?}

Hanne M. Frøyshovs lederartikkel i Tidsskriftet nr. 7/2015 er forunderlig lesing (1). Hun har som hovedpoeng at trombolytisk behandling kan føre til overbehandling og feil prioritering av ressursene, og at slagenhetsbehandling med god margin gir mest helsegevinst på gruppenivå. Vi synes det er overraskende at man ikke vil gi slipp på den gamle idéen om et motsetningsforhold mellom akuttbehandling og slagenhetsbehandling, og at det er gruppen og ikke den enkelte pasient som teller.

Lederartikkelen mer enn antyder at det er trombolytisk overbehandling av «lette hjerneslag», selv om man erkjenner at også denne gruppen har nytte av behandlingen. Denne holdningen er tvetydig, og vi mener den kan bidra til underbehandling av pasienter med mindre hjerneinfarkt. Vår egen erfaring med trombolyse ved lett hjerneinfarkt er god og vi anbefaler slik behandling (2).

Endovaskulær intervensjon (embolektomi) er i dag en vitenskapelig godt dokumentert behandling som forhindrer store hjerneskader og langvarig rehabiliteringsbehov (3). For den enkelte pasient er behandlingen helt avgjørende. Lederartikkelen unnlater å ta stilling til slik behandling.

Videre anbefaler Frøyshov at pasienten med høy prioritet og uten forsinkelse må vurderes av teamet i slagenheten for bl.a. rehabilitering, og at opptrening skal starte så tidlig som mulig. Nyere studier viser imidlertid at det går dårligere med pasienter som får aktiv behandling de første 24 timene $(4,5)$.

Behandling av pasienter med akutt hjerneinfarkt og hjerneblødning har kun ett fokus, og dét er nevrologisk. Hjernevev skal reddes fra en raskt progredierende død. Akuttfasens første minutter dreier seg om nevrologisk og nevroradiologisk diagnostikk, deretter om spesifikk nevrovaskulær eller nevrokirurgisk behandling (trombolyse, embolektomi, hemostase) tilpasset diagnosen. Den subakutte fasen, de neste timene og det første døgnet, dreier seg om stabilisering av vaskulære og nevronale forhold gjennom generell akuttmedisinsk monitorering og behandling, og om videre diagnostisk avklaring. Rehabiliteringsfasen kommer deretter.

Artikkelen inneholder begreper som overbehandling, overforbruk, feil prioritering og risiko for fatal hjerneblødning. Dette synes vi er tendensiøse begreper. Vi, som har lang erfaring og et stort volum akutte slagpasienter, ser en annen virkelighet.

\section{Lars Thomassen}

ltho@haukeland.no

Halvor Næss

Ulrike Waje-Andreassen

Lars Thomassen (f. 1947) er professor og overlege ved Nevrologisk avdeling, Haukeland Universitetssykehus.

Ingen oppgitte interessekonflikter.

Halvor Næss (f. 1957) er professor og overlege ved Slagenheten, Haukeland universitetssykehus.

Ingen oppgitte interessekonflikter. 
Ulrike Waje-Andreassen (f. 1962) er 1. amanuensis og overlege ved Senter for nevrovaskulære sykdommer, Nevrologisk avdeling, Haukeland universitetssykehus.

Ingen oppgitte interessekonflikter
Litteratur

1. Nylenna M. Samvalg - kun et par minutter ekstra. Dagens medisin 2014 ; 7.5 .2014

2. Frøyshov H, Indredavik B, Wyller TB. Indremedisineren, en aktiv bidragsyter i slagbehandlingen. Indremedisineren 2011; 4: 11-3.

\section{Re: Hva er god behandling ved akutt hjerneslag?}

Hjernens fysiologi innebærer en ekstrem sårbarhet for sirkulasjonssvikt, og gjør dermed behandling av hjerneslag til akuttmedisin av fremste klasse. Det eneste målet $\mathrm{i}$ akuttfasen er å begrense hjerneskaden. I sin lederartikkel om god behandling av hjerneslag vektlegger Hanne M. Frøyshov slagenheten med tverrfaglig tilnærming og rehabilitering (1). Hun er nokså skeptisk til «overdreven» trombolytisk behandling. Som vaskulære nevrologer mener vi at Frøyshov i for liten grad forholder seg til moderne kunnskap om hjernens fysiologi. Altfor mange hjerneslagpasienter blir i dag liggende å vente i et akuttmottak mens hjerneceller gradvis dør. Hjerneslagpasienten krever umiddelbar nevrologisk undersøkelse, CT og/eller MR av hjernen og, dersom indikasjon er til stede, trombolytisk og/eller endovaskulær behandling ved et spesialisert sykehus. Det terapeutiske tidsvinduet for intravenøs trombolyse ble først anslått til 3 timer. Senere undersøkelser tydet på at man kunne gi trombolytisk behandling opptil 4,5 timer, men dette er senere trukket i tvil (2).

Det siste halve året har verdens hjerneslagmiljø sydet av entusiasme etter hvert som den ene positive endovaskulære studien etter den andre er publisert. Resultatene innebærer at det må foretas betydelige organisatoriske endringer (3), noe lederartikkelen dessverre ikke diskuterer.

Av ulike årsaker vil ikke alle hjerneslagrammete kunne tilbys reperfusjonsbehandling. Pasientseleksjonen til ulike behandlingsformer krever høy kompetanse innen både prehospital medisin, nevrologi og nevroradiologi. I følge European Stroke Organisations anbefalinger for slagenheter er overvåkning og optimalisering av hjernens perfusjon vel så viktig som tverrfaglighet (4). Frøyshov skriver at opptreningen skal starte så tidlig som mulig. Dette kan være en sannhet med modifikasjoner. Resultatene fra en fersk studie viser at det kan gå dårligere med pasienter som mobiliseres tidlig (innen 24 timer), enn i den subakutte fasen (24-48 timer) (5). Slagenhetens fortreffelighet er for lengst dokumentert, men vi må vokte oss vel slik at fagfeltet får lov til å utvikle seg videre i tråd med kunnskapsomfanget.

Frøyshov konkluderer med at fremtidens slagleger må håndtere blålys og teknologi. For oss vaskulære nevrologer har dette vært en del av hverdagen de siste ti årene. Fremtidens slagleger må ha inngående kunnskap innen nevrologi og nevroradiologi, og et høyt pasientvolum for å kunne individualisere behandlingen slik at mest mulig av hjernen kan bevares.

\section{Mirza Jusufovic}

mirza.jusufovic@medisin.uio.no

Mirza Jusufovic (f. 1980) er lege og stipendiat ved Nevrologisk avdeling, Klinikk for kirurgi og nevrofag, Oslo universitetssykehus. Ingen oppgitte interessekonflikter. Medforfattere: Else Charlotte Sandset, Anne Hege Aamodt, Bjørnar Hassel, Sigrun Kierulf Brækken, Mona Skjelland, Christian Georg Lund

\section{Litteratur}

1. Frøyshov HM. Hva er god behandling ved akutt hjerneslag? Tidsskr Nor Lege foren 2015: 135: 625

2. Alper BS, Malone-Moses M, McLellan JS et al. Thrombolysis in acute ischaemic stroke: time for a rethink? BMJ 2015; 350: h1075

3. Furlan AJ. Endovascular Therapy for Stroke - It's about Time. N Engl J Med 2015.

4. Ringelstein EB, Chamorro A, Kaste M et al: ESO Stroke Unit Certification Committee. European Stroke Organisation recommendations to establish a stroke unit and stroke center. Stroke 2013; 44: 828-40.

5. AVERT Trial Collaboration group. Efficacy and safety of very early mobilisation within $24 \mathrm{~h}$ of stroke onset (AVERT): a randomised controlled trial. Lancet 2015.
Hanne Frøyshov (f. 1967) er overlege ved medisinsk avdeling UNN-Harstad

Ingen oppgitte interessekonflikter. 